\title{
Graded porous solid oxide fuel cells fabricated by multilayer tape casting and co-firing progress
}

\author{
Lifang Nie ${ }^{a *}$, Quan Sun ${ }^{a}$, Ze Liu ${ }^{b}$ and Mingfei Liu ${ }^{b}$ \\ ${ }^{\text {a }}$ School of Materials Science and Engineering, Tianjin Polytechnic University, Tianjin, China \\ ${ }^{\mathrm{b}}$ School of Materials Science and Engineering, Georgia Institute of Technology, Atlanta, GA, \\ USA
}

\begin{abstract}
:
Solid oxide fuel cells (SOFCs) with graded porous cathode were fabricated via a multilayer tape casting and co-firing technique, which is a low-cost and reproducible fabrication process. The effects of pore formers on the electrochemical performance of graded cathode are studied to minimize cathodic polarization resistance. Examination of the microstructures reveals that the multilayer single cell had no delamination, observable cracks, or other large defects. The cell prepared by the co-firing process exhibits low interfacial polarization resistance and high power density at the operating temperature range of $700-800{ }^{\circ} \mathrm{C}$. This simple fabrication technique can be used for optimization of electrode microstructures and cost-effective fabrication of high-performance SOFCs.
\end{abstract}

Keywords: Graded cathode, Multilayer tape casting, Co-firing, Solid Oxide Fuel Cell

\section{Introduction}

Solid oxide fuel cells (SOFCs) have gained remarkable interest in recent years owing to their high efficiency, low emission, and fuel flexibility [1-3]. However, the cost of current SOFC systems is still prohibitive for many practical applications. To be

\footnotetext{
* Phone: +8622 83955012; fax: +86 2283955055

E-mail: nielf2007@126.com
} 
economically competitive, both the cost of materials and the cost of fabrication for SOFC systems must be dramatically reduced [4-5]. One effective approach to cost reduction is to reduce the operating temperature of SOFCs. As a consequence, however, reduction of operating temperature considerably increased electrode polarization resistance, especially the resistance to oxygen reduction at the cathode. To address this problem, many studies have been conducted to develop new electrode materials or composite electrodes with high catalytic activity at relatively low temperatures [6]. Nevertheless, for a given electrode material, the electrode performance can be drastically altered by changing its microstructure, including pore and gain sizes, size distribution, and porosity.

Among various fabrication methods, tape casting is a well-established technique for fabricating large, thin, and flat ceramic tapes with a thickness range of 1-1000 $\mu \mathrm{m}$. The scalability and longstanding success of the tape casting process makes it a legitimate technique for low-cost manufacturing of SOFC components, such as electrolyte membranes, anode supports, and interconnect layers[7-9]. Recently, tape casting and cofiring techniques have been applied to the fabrication of SOFC single cells and have proven to be scalable and cost-effective. A peak power density of $250 \mathrm{~mW} \mathrm{~cm}{ }^{-2}$ at $900{ }^{\circ} \mathrm{C}$ has been obtained in an anode-supported cell with a LSM cathode YSZ electrolyte by screen printing and co-firing[10]. Wang et al. [8] fabricated $\mathrm{Ni} / \mathrm{ScSz}$ anode-supported SOFCs by a multilayer tape casting and co-sintering technique. With the use of a LSCF/GDC composite cathode sintered at $1100{ }^{\circ} \mathrm{C}$, they obtained a maximum power density of $0.85 \mathrm{~W} \mathrm{~cm} \mathrm{~cm}^{-2}$ and an area-specific polarization resistance of $0.336 \Omega \mathrm{cm}^{2}$ at $850{ }^{\circ} \mathrm{C}$. H. Moon [11] developed NiO/YSZ anode-supported SOFCs with an anode active layer via a tape casting and lamination technique. After pressing isostatically for 
$10 \mathrm{~min}$, the half cell with the anode and electrolyte was sintered at $1350{ }^{\circ} \mathrm{C}$ for $3 \mathrm{~h}$. The prepared SOFC with a LSM/YSZ cathode exhibited high power density and low cell resistance of $0.73 \mathrm{~W} \mathrm{~cm}^{-2}$ and $0.35 \Omega \mathrm{cm}^{2}$, respectively, at $700{ }^{\circ} \mathrm{C}$.

Materials in the $(\mathrm{La}, \mathrm{Sr})(\mathrm{Co}, \mathrm{Fe}) \mathrm{O}_{3-\delta}$ family have been extensively investigated and utilized as a cathode for SOFC due to their high ionic and electronic conductivity and good catalytic activity for the oxygen reduction reaction[12-13]. There have been various processes used for the preparation of porous LSCF electrode such as screen printing[14], dip coating[15] and spray painting[16]. To date, most studies on LSCF cathode reported in the literatures focus on cathodes of uniform microstructures. In this communication, we report our findings on fabrication and characterization of porous $\mathrm{La}_{0.6} \mathrm{Sr}_{0.4} \mathrm{Co}_{0.2} \mathrm{Fe}_{0.8} \mathrm{O}_{3-\delta}$ cathodes with graded microstructures fabricated by tape casting. The effect of the amount of pore formers on the performance of the graded cathode was determined. Meanwhile, an anode-supported SOFC cell was fabricated by tape casting and co-firing process to produce a cost-effective single cell that operates at intermediate temperatures. The power density and area specific resistance of the resulting SOFC were evaluated.

\section{Experimental process}

\subsection{Cathode Preparation}

$\mathrm{La}_{0.6} \mathrm{Sr}_{0.4} \mathrm{Co}_{0.2} \mathrm{Fe}_{0.8} \mathrm{O}_{3-\delta}$ powders with varying particle sizes were prepared by citrate method [15] and gelcasting technique [17], respectively. The LSCF powders synthesized by the citrate method (S.A. $14.38 \mathrm{~m}^{2} \cdot \mathrm{g}^{-1}$ ) and gelcasting (S.A. $8.07 \mathrm{~m}^{2} \cdot \mathrm{g}^{-1}$ ) were used for active layer (inner layer) and central layer, respectively. For current collector (top layer),

commercial $\mathrm{La}_{0.6} \mathrm{Sr}_{0.4} \mathrm{Co}_{0.2} \mathrm{Fe}_{0.8} \mathrm{O}_{3-\delta}$ powders (S.A. $1.36 \mathrm{~m}^{2} \cdot \mathrm{g}^{-1}$, Inframat Advanced 
Materials) were applied. Two pore formers were selected: graphite (Alfa Aesar) and corn starch (Sigma-Aldrich). The graphite and the starch were applied for inner layer and top layer and the amounts were from $5 \mathrm{wt} \%$ to $20 \mathrm{wt} \%$ and from $25 \mathrm{wt} \%$ to $40 \mathrm{wt} \%$, respectively. For central layer, $15 \mathrm{vol} \%$ of graphite and $15 \mathrm{vol} \%$ of starch were added to the LSCF slips. In a first step, the LSCF powders and pore formers were ball milled for $12 \mathrm{~h}$ with dispersant in a mixture of xylene and ethanol to form a stable slurry. In a second step, two plasticizers and a commercial bonder were added to confer adequate flexibility and strength to the tapes, and left for further milling for another $12 \mathrm{~h}$. The resulting homogeneous slurry was then cast under doctor blade. The inner layer was cast first on the carrier film and allowed to dry in air for several minutes, then the central layer and the top layer were prepared similarly. The thickness of each layer is $20 \mu \mathrm{m}$. After drying overnight at room temperature, the three layer green tape was cut into disks with diameter of $15 \mathrm{~mm}$. For comparison, $60 \mu \mathrm{m}$ thick single-layer LSCF cathodes of uniform microstructure were also fabricated using the same method.

\subsection{Fabrication of symmetric cell and anode supported cell}

In order to characterize the electrochemically behavior of these cathodes with different microstructures, electrolyte-supported symmetric cells with a configuration of LSCF $\mid$ SDC | YSZ | SDC |LSCF were used. The YSZ electrolyte membranes were fabricated from $8 \mathrm{~mol} \% \mathrm{Y}_{2} \mathrm{O}_{3}$-doped $\mathrm{ZrO}_{2}$ (Tosoh, Japan) using tape casting and sintering at $1400{ }^{\circ} \mathrm{C}$ for $5 \mathrm{~h}$. To avoid the reaction between LSCF cathode and YSZ electrolyte, a $\mathrm{Sm}_{0.2} \mathrm{Ce}_{0.8} \mathrm{O}_{1.95}$ (SDC) buffer layer was applied by drop coating SDC slurry on both sides of the YSZ pellets. The slurry was a mixture of the SDC powder and additives dispersed in an organic solvent. Then the LSCF green tapes were bonded to the buffer layer. After 
dried at $80^{\circ} \mathrm{C}$ for $1 \mathrm{~h}$, the symmetric cells were heated in a furnace at a rate of $3{ }^{\circ} \mathrm{C} / \mathrm{min}$ up to $1080^{\circ} \mathrm{C}$.

The button cell in this study had Ni-YSZ anode supports, Ni-YSZ active layer, YSZ electrolyte, SDC buffer layer and graded LSCF cathodes (shown in Fig.1). Electrolyte thin film and anode were prepared by co-tape casting, which were the same as described in cathode preparation. The YSZ film was cast first, then followed by the anode active layer and anode support. After drying overnight at room temperature, the multilayer green tapes were detached and co-fired at $1400^{\circ} \mathrm{C}$ for $5 \mathrm{~h}$ in air. After that, the graded LSCF cathode was bonded to the YSZ electrolyte using SDC as buffer layer (similar to the symmetric cell fabrication) and subsequently sintered at $1100{ }^{\circ} \mathrm{C}$ for $2 \mathrm{~h}$.

\subsection{Electrochemical and microstructural characterization}

Electrochemical Impedance spectroscopy at open circuit voltage was carried out using a frequency response analyzer (Solartron 1255) in the air at temperatures ranging from $650-800{ }^{\circ} \mathrm{C}$. The frequency was from $10 \mathrm{MHz}$ to $0.01 \mathrm{~Hz}$ and the $\mathrm{AC}$ amplitude was $5 \mathrm{mV}$. All data were collected in 30min after the desired temperature reached. The data was corrected for electrode area, and divided by two (symmetric cell) to obtain the actual interfacial polarization resistance of each electrolyte/electrode interface. The button cell was tested at $700-800{ }^{\circ} \mathrm{C}$ in a home-developed cell testing system with humidified hydrogen $\left(3 \mathrm{vol} \% \quad \mathrm{H}_{2} \mathrm{O}\right)$ as fuel and stationary air as oxidant. The electrochemical performance of cell was recorded with an electrochemistry workstation (CHI 660). The microstructure and morphology of the samples after testing were examined using a scanning electron microscopy (SEM, Hitachi S-4800).

\section{Results and discussion}


Figure 2 shows the interfacial resistancs of the symmetrical cells with the structurally graded LSCF cathodes under open circuit conditions at $650-800{ }^{\circ} \mathrm{C}$. Both the content of graphite for the inner layer and that of corn starch for the outer layer have significant impact on interfacial resistances. At corn starch content of $25 \mathrm{wt} \%$ to $40 \mathrm{wt} \%$, the trends in electrochemical performances show that an increase in the amount of pore former (graphite) for the inner layer reduces the polarization when up to $10 \mathrm{wt} \%$ graphite is used as a pore former. The LSCF cathode that contained $\geq 15 \mathrm{wt} \%$ graphite showed decreased performance relative to the $10 \mathrm{wt} \%$ graphite cathode. In general, cathode reaction in SOFCs occurs within a limited active region in a layer approximately 5-10 $\mu \mathrm{m}$ thick adjacent to the cathode/electrolyte interface. Within the cathode active region, the chemical reaction occurs at the triple phase boundaries (TPBs) of the oxidant gas. Therefore, the inner layer with $10 \mathrm{wt} \%$ graphite can offer the highest surface area and the longest TPB for catalytic reactions. Meanwhile, the interfacial resistances of the graded cathode decreased proportionally with the decrease in content of pore former (corn starch) for the outer layer. The lowest interfacial resistances were achieved at a starch content of $35 \mathrm{wt} \%$ (green line). Furthermore, the increase of starch content resulted in an increase of the resistance. The relatively high porosity of the outer layer allows for rapid transport of oxygen molecules. However, such high porosity also reduces the contact areas between individual LSCF particles, thereby resulting in increased interfacial resistance.

Figure 3 shows the trend of activation energies with graphite when $35 \mathrm{wt} \%$ starch was used as pore former for the outer layer. From the linear fitting, an activation energy of $1.65 \mathrm{eV}$ was obtained for graded cathode with $20 \mathrm{wt} \%$ graphite, which decreased to 1.43 and $1.45 \mathrm{eV}$ for the cathode with 10 and $5 \mathrm{wt} \%$ graphite, respectively. The activation 
energies of the graded LSCF are also in agreement with those reported for the LSCF cathode at temperature range of $600-800{ }^{\circ} \mathrm{C}[18,19]$. When compared with the graded cathode containing $20 \mathrm{wt} \%$ graphite, the cathode with $10 \mathrm{wt} \%$ graphite exhibited much lower polarization resistances, reaching about $0.053,0.11,0.27$, and $0.65 \Omega \mathrm{cm}^{2}$ at 800 , 750, 700, and $650{ }^{\circ} \mathrm{C}$, respectively. Comparison between Fig. 2 and Fig. 3 indicated that the graded LSCF cathode with $10 \mathrm{wt} \%$ graphite and $35 \mathrm{wt} \%$ corn starch had the highest cathodic performance.

Figure 4 shows the typical spectra of graded and single layer LSCF electrode on YSZ measured under open circuit conditions at $750{ }^{\circ} \mathrm{C}$. In order to separate the contributions of the two arcs, an equivalent circuit with two distributed element, similar to that reported in ref. [20] and ref. [21], has been used to fit the data. In this model, Rs represents the intercept of the impedance spectra at high frequency with the real axis; $R_{1}$ and $R_{2}$ refer to the high- and low frequency resistance, respectively. The graded LSCF had $\mathrm{R}_{1}$ and $\mathrm{R}_{2}$ equal to $102 \mathrm{~m} \Omega \cdot \mathrm{cm}^{2}$ and $8 \mathrm{~m} \Omega \cdot \mathrm{cm}^{2}$ at $750{ }^{\circ} \mathrm{C}$, respectively, as compared to $152 \mathrm{~m} \Omega \cdot \mathrm{cm}^{2}$ and $31 \mathrm{~m} \Omega \cdot \mathrm{cm}^{2}$ at the same temperature for single cathode. It is reported that the high frequency arc related to the transfer of oxide ions across the electrode/electrolyte interface and the low frequency was attributed to surface exchange reactions and gaseous diffusion [22]. This supports the view that both charge transfer reactions and the oxygen mass transport were enhanced for graded porous cathode.

Figure 5 shows the cross-section SEM image of a co-fired single cell with LSCF graded cathode. Figure 5a indicates that the dense YSZ electrolyte film is approximately $15 \mu \mathrm{m}$ and thoroughly adheres to the porous anode substrate. To enhance cell performance, an anode active layer ( 10 $\mu \mathrm{m}$ thick) having fine microstructure was used 
at the anode-electrolyte interface. The cells of these layers had no delamination, observable cracks, or other large defects. The three-layer LSCF cathodes with thickness of approximately $50 \mu \mathrm{m}$ are graded in both porosity and grain size (Fig. $5 \mathrm{~b}$ ). The inner layer has the lowest porosity and finest grains $(\sim 0.5 \mu \mathrm{m}$ diameter $)$, followed by the midlayer with slightly larger grain size $(\sim 1 \mu \mathrm{m}$ diameter $)$ and relatively coarser microstructure, and then the outer layer, which has the largest grains $(\sim 1.5 \mu \mathrm{m}$ diameter $)$ and highest porosity. The large interconnected pores in the top layer allow rapid transport of oxygen molecules, whereas the considerably long TPB in the inner layer facilitates catalytic reactions.

Figure 6 shows the current-voltage (I-V) and current-power densities (I-P) curves of an anode-supported SOFC with the optimum grade LSCF cathode. The values were measured at $700-800{ }^{\circ} \mathrm{C}$, in which hydrogen and ambient air were used as fuel and oxidant, respectively. The open circle voltage of the cell under the operating conditions is $\sim 1.07 \mathrm{~V}$ at $750{ }^{\circ} \mathrm{C}$, which is close to the theoretical value calculated from the Nernst equation. This finding indicates that the YSZ electrolyte is sufficiently dense without any cross cracks or pinholes. The peak power density reached 378,622 , and $1001 \mathrm{~mW} \cdot \mathrm{cm}^{-2}$ at 700,750 , and $800{ }^{\circ} \mathrm{C}$, respectively. The power density at $800{ }^{\circ} \mathrm{C}$ is more than twofold that for a similar cell Ni/Ni-YSZ/YSZ/LSCF fabricated by a deposition and co-sintering process in a previous report[23]. These power outputs are also higher than that of the same cell with LSM-SSZ cathode, specifically, 800,550 , and $370 \mathrm{~mW} \cdot \mathrm{cm}^{-2}$ at the corresponding temperatures[24]. Le et al. [25] and Myung et al.[26] reported power densities of 856 and $650 \mathrm{~mW} \cdot \mathrm{cm}^{-2}$ in humidified $\mathrm{H}_{2}$ at $800{ }^{\circ} \mathrm{C}$ for NiO-YSZ anode- 
supported cells with LSM-YSZ cathodes fabricated by co-tape casting and co-firing technique, respectively.

Figure 7 shows the impedance spectra of the single cell measured at 700,750 and $800^{\circ} \mathrm{C}$ under open circuit condition. The intercepts of the impedance arcs on the real axis at high frequencies correspond to the ohmic resistance, which mainly comes from the electrolyte and lead wires, while the overall size of the impedance loop is attributed to the polarization resistance of the electrodes. As the operating temperature was increased from 700 to $800^{\circ} \mathrm{C}$, the polarization resistances of the cell were reduced from 0.57 to 0.38 $\Omega \mathrm{cm}^{2}$ while the ohmic resistance decreased from 0.53 to $0.23 \Omega \mathrm{cm}^{2}$. As expected, both the ohmic loss and the polarization decreased with increasing temperature, due to the increased ionic conductivity of the electrolyte and faster electrode kinetics.

\section{Conclusions}

NiO-YSZ anode-supported SOFCs with graded porous cathodes were fabricated via a low-cost multilayer tape casting and co-firing technique. Based on interfacial resistance characterization, the three-layer LSCF cathode with $10 \mathrm{wt} \%$ graphite for inner-layer and $35 \mathrm{wt} \%$ corn starch for outer-layer had the highest cathodic performance. Compared with the single-layer LSCF cathode, both charge transfer reactions and the oxygen mass transport were enhanced for the graded porous cathode. The maximum power densities of the prepared button cell reached 378,622 , and $1001 \mathrm{~mW} \cdot \mathrm{cm}^{-2}$ at 700,750 , and $800{ }^{\circ} \mathrm{C}$, respectively. The polarization resistances of the cell were estimated to be $0.38,0.43$, and $0.57 \mathrm{~cm}^{2}$ at the corresponding temperatures. 


\section{Acknowledgement}

This work was supported by the National Nature Science Foundation of China Program under award number 51202161 and the U.S. Department of Energy SECA Core Technology Program under award number DE-NT0006557. 


\section{Reference}

[1] Liu ML, Lynch ME , Blinn K. Rational SOFC material design:new advances and tools. Mater Today 2011;14:534-546.

[2] Yang L, Cheng Z, Liu ML. New insights into sulfur poisoning behavior of Ni-YSZ anode from long-term operation of anode-supported SOFCs. Energy Environ Sci 2010; 3:1804-1809.

[3] Liu MF, Choi Y, Qin WT. Direct octane fuel cells: a promising power for transportation. Nano Energy 2012;1:448-455.

[4] Jiang SP, Zhang L, Zhang YJ. Lanthanum strontium manganese chromite cathode and anode synthesized by gel-casting for solid oxide fuel cells. J Mater Chem 2007;17:2627-2635.

[5] Dai HL, Chen H, He SC. Improving solid oxide fuel cell performance by a single-step co-firing process. J Power Sources 2015;286:427-430.

[6] Jiang ZY, Xia CR, Chen FL. Nano-structured composite cathodes for intermediate-temperature solid oxide fuel cells via an infiltration/impregnation technique. Electrochimica Acta 2010;55:35953605 .

[7] Timakul P, Jinawath S, Aungkavattana P. Fabrication of electrolyte materials for solid oxide fuel cells by tape-casting. Ceram Int 2008;34:867-871.

[8] Wang ZR, Qian JQ, Wang SR. Improvement of anode-supported solid oxide fuel cells. Solid State Ionics 2008;179:1593-1596.

[9] Compson C, Liu ML. Fabrication and characterization of hermetic solid oxide fuel cells without sealant. Solid State Ionics 2006;177:367-395.

[10] Montinaro D, Sglavo VM, Bertodi M . Tape casting fabrication and co-sintering of solid oxide "half cell” with a cathode-electrolyte porous interface. Solid State Ionics 2006;177:2093-2097.

[11] Moon H, Kim SD, Park EW. Characteristics of SOFC single cells with anode active layer via tape casting and co-firing. Int J Hydrogen Energ 2008;33:2826-2833.

[12] Chen Jing, Liang FL, Chi B. Palladium and ceria infiltrated $\mathrm{La}_{0.8} \mathrm{Sr}_{0.2} \mathrm{Co}_{0.5} \mathrm{Fe}_{0.5} \mathrm{O}_{3-\delta}$ cathodes of solid oxide fuel cells. J Power Sources 2009;194:275-280.

[13] Nie LF, Liu JC, Zhang YJ. Effects of pore formers on microstructure and performance of cathode membranes for solid oxide fuel cells. J Power Sources 2011;196:9975-9979.

[14] Fu Q, Sun KN, Zhang NQ. Optimization on fabrication and performance of A-site-deficient $\mathrm{La}_{0.58} \mathrm{Sr}_{0.4} \mathrm{Co}_{0.2} \mathrm{Fe}_{0.8} \mathrm{O}_{3-\delta}$ cathode for SOFC. J Solid State Electrochemical 2009;13:455-467.

[15] Liu Z, Han MF, Miao WT. Preparation and characterization of graded cathode $\mathrm{La}_{0.6} \mathrm{Sr}_{0.4} \mathrm{Co}_{0.2} \mathrm{Fe}_{0.8} \mathrm{O}_{3-\delta}$. J Power Sources 2007;173:837-841.

[16] Hsu CS, Hwang BH. Microstructure and Properties of the $\mathrm{La}_{0.6} \mathrm{Sr}_{0.4} \mathrm{Co}_{0.2} \mathrm{Fe}_{0.8} \mathrm{O}_{3}$ Cathodes Prepared by Electrostatic-Assisted Ultrasonic Spray Pyrolysis Method. J Electrochem Soc 2006;153(8):A1478-A1483. 
[17] Wang HT, Xie S, Lai W. Preparation and characterization of perovskite ceramic powders by gelcasting. J Mater Sci 1999;34:1163-1167.

[18] Zhao H, Huo L, Sun L. Preparation, chemical stablility and electrochemical properties of LSCFCBO composite cathodes. Mater Chem Phys 2004; 88:160-166.

[19] Liu SM, Qian XL, Xiao JZ. Synthesis and characterization of $\mathrm{La}_{0.8} \mathrm{Sr}_{0.2} \mathrm{Co}_{0.5} \mathrm{Fe}_{0.5} \mathrm{O}_{3 \pm \delta}$ nanopowders by microwave assisted sol-gel route. J Sol-Gel Sci Technol 2007; 44:187-193.

[20] Xia CR, Rauch W, Wellborn W. Functionally Graded Cathodes for Honeycomb Solid Oxide Fuel Cells. Electrochemical and Solid-State Letters 2002;5:A217-A220.

[21] Liu SM, Suo JP, Xiao JZ. Effects of surface overpotential at the $\mathrm{La}_{1-\mathrm{x}} \mathrm{Sr}_{\mathrm{x}} \mathrm{Co}_{1-\mathrm{y}} \mathrm{Fe}_{\mathrm{y}} \mathrm{O}_{3-\delta}$ yttria stabilized zirconia interface in a model solid oxide fuel cell cathode. Int J Hydrogen Energ 2008; 33:6322-6326.

[22] Baumann FS, Fleig J, Habermeier HU. Impedance spectroscopic study on well-defined $(\mathrm{La}, \mathrm{Sr})(\mathrm{Co}, \mathrm{Fe}) \mathrm{O}_{3-\delta}$ model electrodes. Solid State Ionics 2006;177:1071-1081.

[23] Cho HJ, Choi GM . Fabrication and characterization of Ni-supported solid oxide fuel cell. Solid State Ionics 2009;180:792-795.

[24] Wang CC, Luo LH, Wu YF. A novel multilayer aqueous tape casting method for anodesupported planar solid oxide fuel cell. Mater Lett 2011; 65:2251-2253.

[25] Le SR, Sun KN, Zhang NQ. Fabrication and evaluation of anode and thin $\mathrm{Y}_{2} \mathrm{O}_{3}$-stabilized $\mathrm{ZrO}_{2}$ film by co-tape casting and co-firing technique. J Power Sources 2010;195:2644-2648.

[26] Myung J, Ko HJ, Park H. Fabrication and characterization of planar-type SOFC unit cells using the tape-casting/lamination/co-firing method. Int J Hydrogen Energ 2012; 37:498-504. 


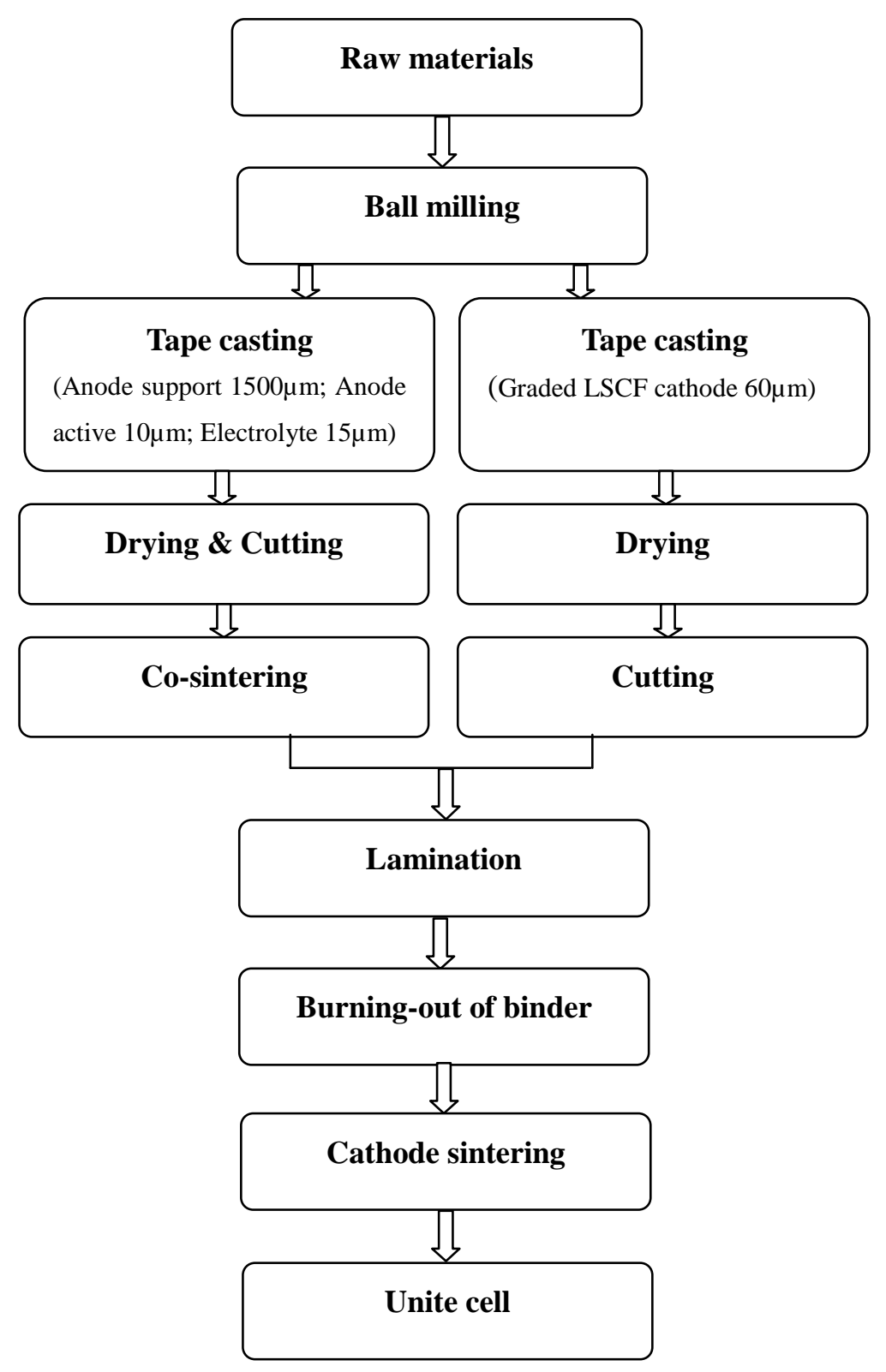

Fig.1. Flow chart of the manufacturing procedure for unit cell. 

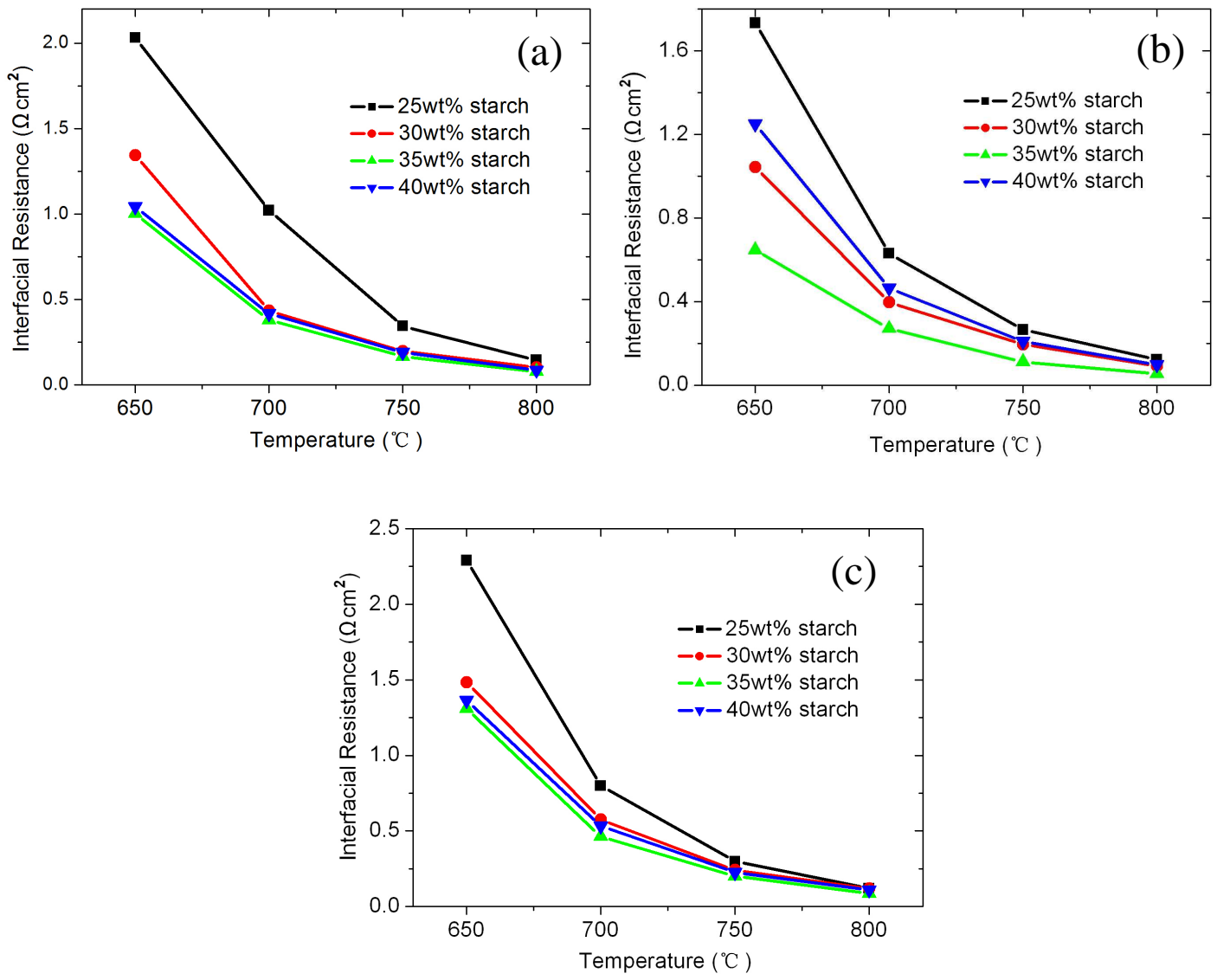

Fig.2. Effect of pore former content on electrochemical performance of LSCF cathodes: (a) $5 \mathrm{wt} \%$ graphite; (b) $10 \mathrm{wt} \%$ graphite and (c) $15 \mathrm{wt} \%$ graphite. 


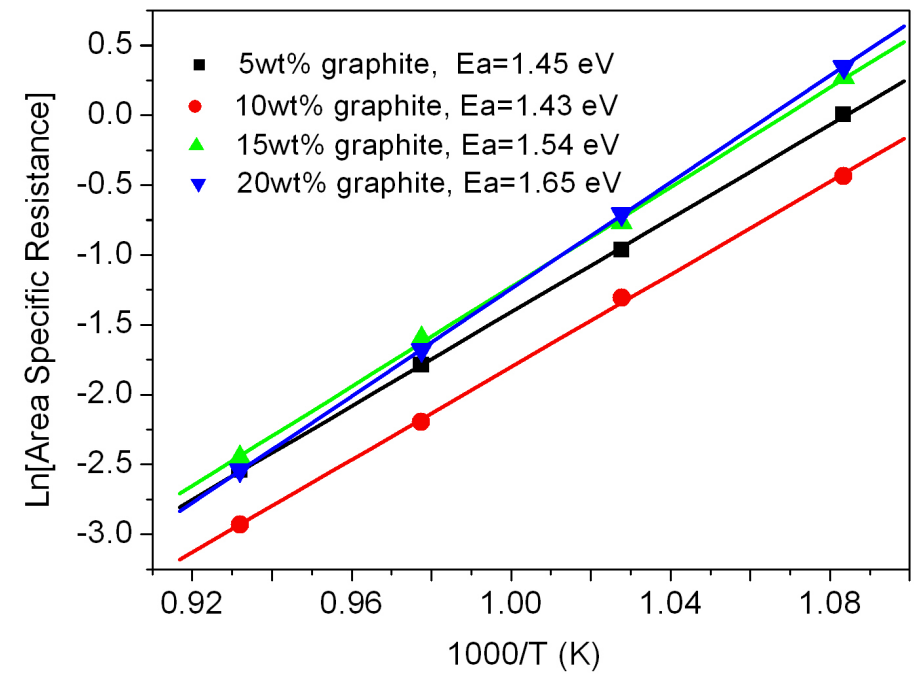

Fig.3. Arrhenius curve for different graphite content. 


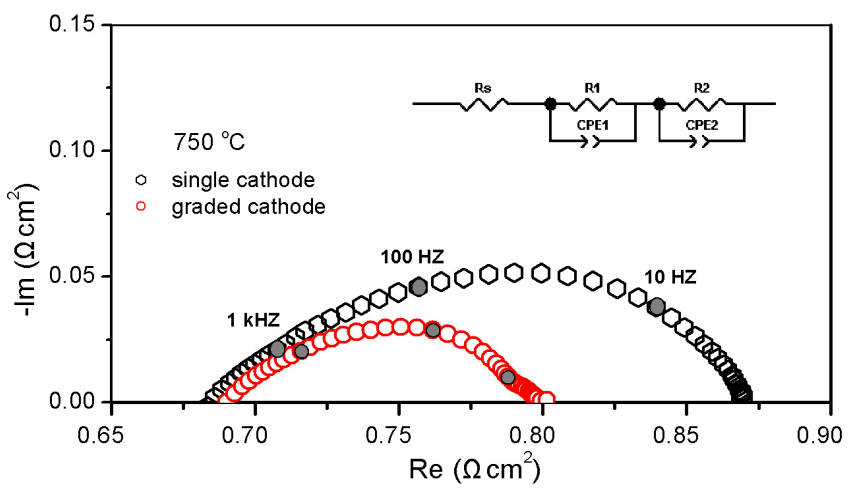

Fig. 4. AC impedance spectra of graded cathode, compared to the response from the single cathode at $750{ }^{\circ} \mathrm{C}$. 

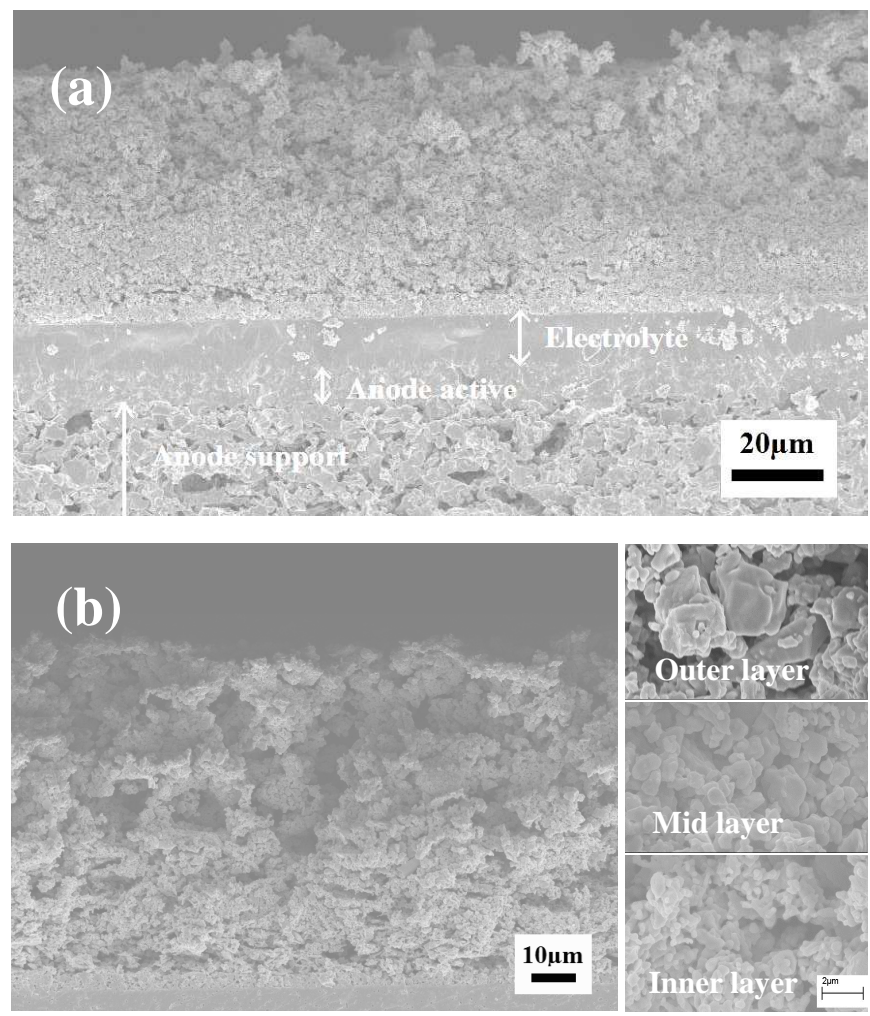

Fig.5. (a)SEM micrograph of cross-sections of a single cell; (b)Cross-sectional fracture surface of the graded LSCF cathode and grain morphology. 


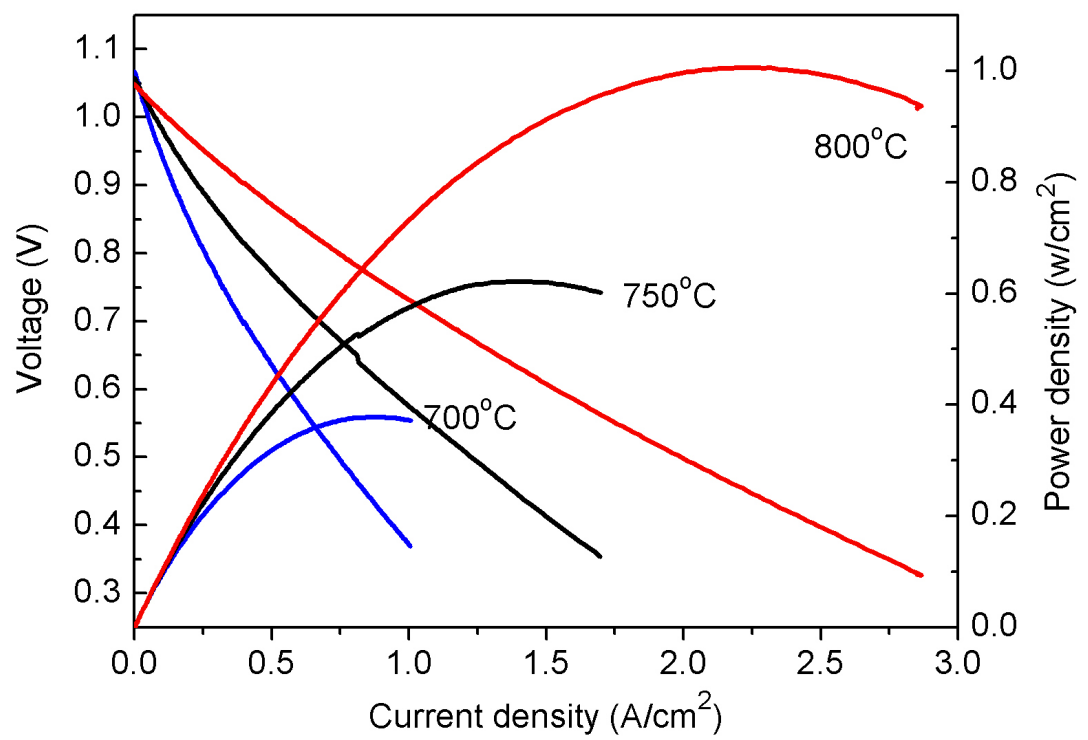

Fig.6. I-V and I-P curves of cells with graded LSCF cathodes at different temperatures. 


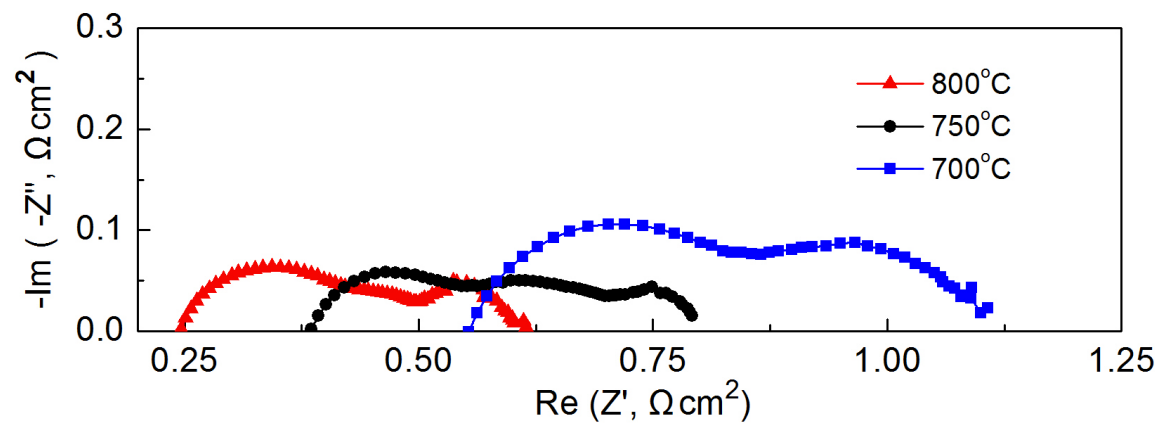

Fig.7 Impedance spectra of a single cell with graded LSCF cathode measured under open circuit conditions at different temperatures. 